\title{
Brown Tumor and Hyperparathyroidism in Orthopaedic Surgery
}

\author{
Ortopedide Brown Tümörü ve Hiperparatiroidizme Yaklaşım \\ (D) Yunus Öç, (D) Bekir Eray Kılınç*, (D) Onur Gültekin*, (D) Ethem Aytaç Yazar*, (D) Ali Varol***, \\ (D) Hacı Mustafa Özdemir** \\ Bağcllar Medilife Hospital, Clinic of Orthopedics Surgery and Traumatology, Istanbul, Turkey \\ *University of Health Sciences Turkey, Istanbul Fatih Sultan Mehmet Training and Research Hospital, Clinic of Orthopedics Surgery and Traumatology, \\ istanbul, Turkey \\ **University of Health Sciences Turkey, Istanbul Şişli Hamidiye Etfal Training and Research Hospital, Clinic of Orthopedics Surgery and Traumatology, \\ istanbul, Turkey \\ ***Silopi State Hospital, Clinic of Orthopedics Surgery and Traumatology, Şırnak, Turkey
}

\section{Abstract}

Objective: This study aimed a better diagnosis for patients with primary hyperparathyroidism (PHPT), who could be referred to misdiagnosis and treatment and be able to demonstrate a well analysis of patient before orthopaedic surgery.

Materials and Methods: A total of 12 patients admitted to our orthopaedics outpatient clinic between 2003 and 2017, examined and treated due to the bone lesion or fracture and diagnosed with PHPT, were included in this study. Patients were referred to the general surgery clinic for adenectomy. Direct radiograph was used to follow cysts recession after adenectomy.

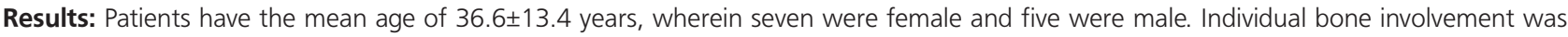
observed in three patients, whereas nine patients had multiple bone involvement. Eight patients had pathological fractures. Biopsy was conducted on all patients, revealing an increased osteoclastic activity and multinuclear giant cells, and a report was issued for these findings. Conclusion: Brown tumor is very rare reactive lesions developed in bone tissues during hyperparathyroidism. In order to make a definitive diagnosis for the cystic and lytic lesions, suspecting the patient's clinical status and keeping any possible diagnosis in mind is necessary. Keywords: Brown tumor, giant cell tumour, primary hyperparathyroidism, metastatic bone lesion

\section{$\ddot{O z}$}

Amaç: Primer hiperparatiroidizmi (PHPT) olup yanlış tanı ve tedaviye yönlendirilebilecek hastalar için, ortopedik cerrahi öncesinde daha iyi analiz edilmesine yol gösterecek bir çalışma planladık.

Gereç ve Yöntem: 2003-2017 yılları arasında ortopedi polikliniğimize başvuran, kemik lezyonu veya kırı̆̆ı nedeniyle muayene edilip tedavi edilen ve PHPT tanısı alan 12 hasta çalışmaya alındı. Hastalar adenektomi için genel cerrahi kliniğine sevk edildi. Adenektomi sonrası kistlerin durgunluğunu takip etmek için direkt radyografi kullanıldı.

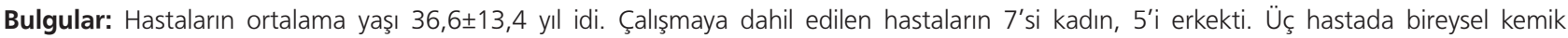
tutulumu gözlenirken, 9 hastada çoklu kemik tutulumu gözlendi. Sekiz hastada patolojik kırık vardı. Artmış osteoklastik aktivite ve çok çekirdekli dev hücreler gösteren tüm hastalara biyopsi yapıldı ve bu bulgular için bir rapor yayınlandı.

Sonuç: Brown tümör, hiperparatiroidizm sırasında kemik dokularında gelişen çok nadir reaktif lezyonlardır. Kistik ve litik lezyonlar için kesin bir tanı koymak için, hastanın klinik durumundan şüphelenmek ve olası herhangi bir tanıyı akılda tutmak gerekir.

Anahtar kelimeler: Brown tümör, dev hücreli tümör, primer hiperparatiroidizm, metastatik kemik lezyonu

\section{Introduction}

Primary hyperparathyroidism (PHPT) is the most common cause of hypercalcemia in patients with asymptomatic hypercalcemia, who applies to the hospital outpatient clinics. Its prevalence rate is $1 / 1,000$ person. Although it can be observed in all age groups, it is mostly observed in individuals at the age of 60s. Female to male ratio of PHPT is $3 / 2$. The main finding of PHPT is the presence of elevated calcium and parathyroid hormone (PTH) levels (1).

Address for Correspondence/Yazışma Adresi: Bekir Eray Kılınç MD, University of Health Sciences Turkey, İstanbul Fatih Sultan Mehmet Training and Research Hospital, Clinic of Orthopedics Surgery and Traumatology, İstanbul, Turkey

Phone: +90 5306061884 E-mail: dreraykilinc@gmail.com ORCID ID: orcid.org/0000-0003-1229-9815

Received/Geliş Tarihi: 18.01.2020 Accepted/Kabul Tarihi: 29.07.2020

${ }^{\circ}$ Copyright 2021 by the Turkish Osteoporosis Society / Turkish Journal of Osteoporosis published by Galenos Publishing House 
Hyperparathyroidism (HPT) may be accompanied with endocrinological weakness and getting exhausted quickly. Symptoms related to the renal and skeletal system are also observed. Early detection of the disease provides a minimal demineralization in the skeletal system $(2,3)$. In general, nothing is detected as a radiological finding, but less frequently osteoporosis is observed. Other skeletal system findings include subperiosteal resorption of the distal phalanx, thinning of the distal ends of the clavicle, salt and pepper appearance of the skull, bone cysts in long bones, and Brown tumors (BTs).

BTs are very rare reactive lesions developed in the bone tissues during HPT. They represent $1 \%$ of all tumor-like bone lesions and $5 \%$ of all primary benign bone tumors (4). BTs, which are one of the subgroups of giant cell tumors (GCT), are caused by excessive proliferation of osteoclasts as a result of a hormonal stimulus. Osteoclast-rich tumors are brown. The source of the color is hemosiderin pigment, which occurs as a result of hemorrhage due to rich vein network it contains (3). Although there are no characteristic findings, all giant cell lesions may be BTs $(5,6)$. It is important to remember that BT is not a pathognomonic finding for HPT. The most important factor in establishing the correct diagnosis is to suspect possible pathologies.

This study included the patients who were admitted to the orthopaedic clinic with HPT. We aimed to report better orthopaedics approach for these patients to avoid the misdiagnosis and wrong surgical treatment.

\section{Materials and Methods}

This study was approved by the Fatih Sultan Mehmet Training and Research Hospital Institutional Review Board/Ethics Committee and conducted according to the ethical principles stated in the Declaration of Helsinki (decision no: 17073117-050.06, date: 03.02.2020). After approval of the institutional review board, informed consent was obtained from the all participants.

This retrospective study included 12 patients who were admitted to our orthopaedics outpatient clinic between 2003 and 2017 with bone lesions. Patients were examined and treated due to the bone lesion or fracture, and diagnosed with PHPT, were included in the study. Laboratory tests were performed for the patients. Endocrinology consultation was requested for patients who had HPT. Patients were confirmed to have no secondary or tertiary HPT after parathyroid scintigraphy, thyroid ultrasound, renal function tests, chest radiographs and all abdominal computed tomographies (CTs) were taken. As a result of these tests parathyroid adenoma was detected in all patients. The patients were referred to the general surgery clinic for adenectomy. Direct radiograph was used to follow the recession of the cysts after adenectomy.

\section{Statistical Analysis}

There was no statistical analysis applied in the study. This study was designed as a case series.

\section{Results}

The mean age of the patients was $36.6 \pm 13.4$ years and 7 of the patients included in the study were female, while 5 were male. In 8 patients, pathological fractures were detected in different bone regions. One patient was operated for the cyst. Individual bone involvement was observed in 3 patients while 9 patients had multiple bone involvement. Demographic data, place of involvement, fracture locations, laboratory findings and treatment modalities are presented in Table 1.

Biopsy was conducted in all patients which revealed increased osteoclastic activity and multinuclear giant cells. Each patient with cyst did not receive any additional operation other than stabilization since the calcium, phosphorus and PTH values that were found to be compatible with HPT. Only the patient numbered 9, who had biopsy, had curettage and grafting in the second session due to the fact that the lesion in the talus was isolated and involved a large part of the talus to prevent early load and fracture.

Two patients were operated another orthopaedic clinic for eccentric bone tumor. Tumor resection prosthesis was performed for a patient with the diagnosis of osteosarcoma, while other patient underwent curettage and grephonage due to a GCT of bone (Figure 1).

Cysts and fractures of our patients were tried to be treated by using non-surgical methods. The most simple and comfortable method was tried to be chosen for the fractures requiring surgery (Figure 2). The main purpose of the surgery was to protect the patient's own bone tissue and not to treat cysts (such as giant cell bone tumor or malignant tumors).

During follow-up, bone fusion was observed, cysts were seen to be regressed, and the patient was observed to gain her healthy bone tissue rapidly following the adenectomy (Figure 3).

\section{Discussion}

BTs are very rare reactive lesions developed in the bone tissues during HPT. In order to make a definitive diagnosis for the cystic and lytic lesions, it is necessary to suspect the patient's clinical status and to keep any possible diagnosis in mind to prevent the wrong and over treatments in orthopaedics.

These tumoral structures associated with PHPT are reversible pathologies that can be healed through the excision of the parathyroid adenomas or removal of the glands $(3,4)$. Following removal of the adenoma, osteoclastic activity stops suddenly and bone healing is observed instead of bone destruction $(5,7)$. However, it is possible to leave them in areas where there are multi-localized BTs (8).

In the diagnosis of PHPT pathology, serum calcium, phosphorus, alkaline phosphatase and PTH are more significant than the histopathological examination. In HPT, GCTs are smaller and have a nodular appearance and they particularly have rounded hemorrhage foci; their stromal cells are more spindle-shaped and tender. The presence of bone metaplasia in stroma is also important. In these regions, osteoclastic and osteoblastic 


\begin{tabular}{|c|c|c|c|c|c|c|c|}
\hline $\begin{array}{l}\text { Patient } \\
\text { no. }\end{array}$ & Gender & Age & Complaint & Involvement & Fracture & Laboratory & Treatment \\
\hline 1 & $\mathrm{~F}$ & 12 & $\begin{array}{l}\text { Pain and } \\
\text { functional } \\
\text { limitation and } \\
\text { Fracture findings }\end{array}$ & $\begin{array}{l}\text { Humerus, } \\
\text { radius, femur, } \\
\text { tibia, ribs, iliac, } \\
\text { mandible }\end{array}$ & $\begin{array}{l}\text { Femoral neck } \\
\text { and diaphysis, } \\
\text { humerus }\end{array}$ & $\begin{array}{l}\text { Ca: } 9.9 \text { mg/dL, P: } \\
2.6 \mathrm{mg} / \mathrm{dL}, \mathrm{PTH}: \\
142 \mathrm{pg} / \mathrm{mL}\end{array}$ & $\begin{array}{l}\text { Adenomectomy } \\
\text { for fractures } \\
\text { conservative }\end{array}$ \\
\hline 2 & M & 20 & $\begin{array}{l}\text { Pain and fracture } \\
\text { formed } 2 \text { months } \\
\text { ago }\end{array}$ & $\begin{array}{l}\text { Humerus, } \\
\text { femur }\end{array}$ & Humerus & $\begin{array}{l}\text { Ca: } 14.1 \mathrm{mg} / \mathrm{dL}, \mathrm{P}: \\
2.28 \mathrm{mg} / \mathrm{dL}, \mathrm{PTH}: \\
738 \mathrm{pg} / \mathrm{mL}\end{array}$ & $\begin{array}{l}\text { Adenomectomy } \\
\text { for fractures } \\
\text { conservative }\end{array}$ \\
\hline 3 & $\mathrm{~F}$ & 25 & $\begin{array}{l}\text { Pain and } \\
\text { difficulty in } \\
\text { walking }\end{array}$ & $\begin{array}{l}\text { Femur, tibia, } \\
\text { fibula, rib, } \\
\text { scapula, radius, } \\
\text { metacarpus, } \\
\text { phalanx, s. } \\
\text { pubis }\end{array}$ & No & $\begin{array}{l}\text { Ca: } 10.8 \mathrm{mg} / \mathrm{dL}, \mathrm{P}: \\
1.8 \mathrm{mg} / \mathrm{dL}, \mathrm{PTH}: \\
1,385 \mathrm{pg} / \mathrm{mL}\end{array}$ & $\begin{array}{l}\text { Adenomectomy } \\
\text { conservative for cysts }\end{array}$ \\
\hline 4 & $\mathrm{~F}$ & 31 & $\begin{array}{l}\text { Pain and } \\
\text { movement } \\
\text { limitation }\end{array}$ & Femur neck & Femur neck & $\begin{array}{l}\text { Ca: } 10.5 \mathrm{mg} / \mathrm{dL}, \mathrm{P}: \\
2.1 \mathrm{mg} / \mathrm{dL}, \mathrm{PTH}: \\
419 \mathrm{pg} / \mathrm{mL}\end{array}$ & $\begin{array}{l}\text { Adenomectomy }+ \\
\text { osteosynthesis with } \\
\text { cannula screw for } \\
\text { fracture }\end{array}$ \\
\hline 5 & $\mathrm{~F}$ & 19 & $\begin{array}{l}\text { Widespread } \\
\text { body pain } \\
\text { and shoulder } \\
\text { prosthesis } \\
\text { application and } \\
\text { tumor diagnosis } \\
\text { at the age of } 16\end{array}$ & $\begin{array}{l}\text { Vertebra, } \\
\text { sacrum, iliac, } \\
\text { ribs }\end{array}$ & No & $\begin{array}{l}\text { Ca: } 15.7 \mathrm{mg} / \mathrm{dL}, \mathrm{P}: \\
2.3 \mathrm{mg} / \mathrm{dL}, \mathrm{PTH}: \\
1,548 \mathrm{pg} / \mathrm{mL}\end{array}$ & $\begin{array}{l}\text { Adenomectomy } \\
\text { conservative for cysts }\end{array}$ \\
\hline 6 & M & 46 & Fracture findings & $\begin{array}{l}\text { Both femur, } \\
\text { cranium, } \\
\text { humerus, tibia }\end{array}$ & $\begin{array}{l}\text { Femur } \\
\text { diaphysis }\end{array}$ & $\begin{array}{l}\text { Ca: } 11.2 \mathrm{mg} / \mathrm{dL}, \mathrm{P}: \\
3.8 \mathrm{mg} / \mathrm{dL}, \mathrm{PTH}: \\
724 \mathrm{pg} / \mathrm{mL}\end{array}$ & $\begin{array}{l}\text { Adenomectomy } \\
+ \text { osteosynthesis with } \\
\text { femoral nail }\end{array}$ \\
\hline 7 & $\mathrm{~F}$ & 34 & $\begin{array}{l}\text { Pain and } \\
\text { movement } \\
\text { limitation }\end{array}$ & $\begin{array}{l}\text { Femur, } \\
\text { humerus }\end{array}$ & Humerus & $\begin{array}{l}\text { Ca: } 9 \text { mg/dL, P: } 2 \\
\text { mg/dL, PTH: } 956 \\
\text { pg/mL }\end{array}$ & $\begin{array}{l}\text { Adenomectomy } \\
\text { conservative for cysts } \\
\text { and fractures }\end{array}$ \\
\hline 8 & M & 49 & Fracture findings & Femur & $\begin{array}{l}\text { Femur } \\
\text { supracondylar }\end{array}$ & $\begin{array}{l}\text { Ca: } 13 \mathrm{mg} / \mathrm{dL}, \mathrm{P}: \\
1.7 \mathrm{mg} / \mathrm{dL}, \mathrm{PTH}: \\
1,008 \mathrm{pg} / \mathrm{mL}\end{array}$ & $\begin{array}{l}\text { Adenomectomy } \\
+ \text { osteosynthesis with } \\
\text { plate }\end{array}$ \\
\hline 9 & M & 66 & Ankle pain & Talus & No & $\begin{array}{l}\text { Ca: } 13.2 \mathrm{mg} / \mathrm{dL}, \mathrm{P}: \\
1.4 \mathrm{mg} / \mathrm{dL}, \mathrm{PTH}: \\
912 \mathrm{pg} / \mathrm{mL}\end{array}$ & $\begin{array}{l}\text { Adenomectomy } \\
+ \text { curettage and grafting }\end{array}$ \\
\hline 10 & $\mathrm{~F}$ & 38 & $\begin{array}{l}\text { Widespread } \\
\text { body pain and } \\
\text { fracture findings } \\
+ \text { curettage } \\
\text { and grafting for } \\
\text { eccentric talus }\end{array}$ & $\begin{array}{l}\text { Femur, talus, } \\
\text { iliac, foot } \\
\text { phalanx }\end{array}$ & $\begin{array}{l}\text { Femur } \\
\text { diaphysis }\end{array}$ & $\begin{array}{l}\text { Ca: } 12.9 \mathrm{mg} / \mathrm{dL}, \mathrm{P}: \\
2.2 \mathrm{mg} / \mathrm{dL}, \mathrm{PTH}: \\
1,025 \mathrm{pg} / \mathrm{mL}\end{array}$ & $\begin{array}{l}\text { Adenomectomy } \\
+ \text { osteosynthesis with } \\
\text { femoral nail }\end{array}$ \\
\hline 11 & M & 48 & Hip pain & Acetabulum & Acetabulum & $\begin{array}{l}\text { Ca: } 10.7 \mathrm{mg} / \mathrm{dL}, \mathrm{P}: \\
2.7 \mathrm{mg} / \mathrm{dL}, \mathrm{PTH}: \\
1,014 \mathrm{pg} / \mathrm{mL}\end{array}$ & $\begin{array}{l}\text { Adenectomy + } \\
\text { osteosynthesis with } \\
\text { screw + grafting }\end{array}$ \\
\hline 12 & $\mathrm{~F}$ & 52 & $\begin{array}{l}\text { Ankle and knee } \\
\text { pain }\end{array}$ & $\begin{array}{l}\text { Tibia, femur, } \\
\text { fibula, iliac }\end{array}$ & No & $\begin{array}{l}\text { Ca: } 11.4 \mathrm{mg} / \mathrm{dL}, \mathrm{P} \text { : } \\
1.5 \mathrm{mg} / \mathrm{dL}, \mathrm{PTH}: \\
825 \mathrm{pg} / \mathrm{mL}\end{array}$ & $\begin{array}{l}\text { Adenectomy + } \\
\text { conservative }\end{array}$ \\
\hline
\end{tabular}

activities improved with peritrabecular fibrosis may be observed In our case series, biopsy was performed during the fracture surgery which revealed mature bone lamellae with multinuclear giant cells accompanied by mild mononuclear inflammatory cell infiltration. Bone tissues showing fibrosis and mildly inflamed reactive changes, focal bone resorption, and increased osteoclastic activity were also observed in the biopsy results. Due to this pathology, it is not possible to differentiate GCT and 
BT. In the diagnosis of BTs, histopathologic examination helps to differentiate malignancy to a certain extent, however, it is not enough alone to make the final diagnosis.

GCTs are locally aggressive lesions containing connective tissues and stromal cells. They are usually present in bone metastases and are mostly located in the femur, tibia, radius, and humerus $(3,5)$. Apart from long bones, they can be seen in the bones of the hand by $5 \%$. The tumor can have monofocal or multifocal localization. Serum calcium level is the only beneficial laboratory finding to be used. This lesion is radiologically seen as lucent and expansile and looks like the enchondroma of the bone or aneurysmal bone cyst (5). In a study by Cicconetti et al. (9), it has been reported that the differential diagnosis of BT is very difficult which may be attributed to the fact that similar radiological images (cyst-like radiolucent) are seen in other pathologies. Morano et al. (7) reported in their study that the diagnosis of the patients was osteocalcytoma until their patients were diagnosed with PHPT in recovery period. They removed the parathyroid adenoma and found that their pathological diagnosis was BT. In our study, PHPT was tried to be excluded by performing biochemical laboratory tests to each patient whose initial diagnosis was bone cyst or lytic lesion when they admitted to the outpatient clinic. It should be kept in mind that BTs may
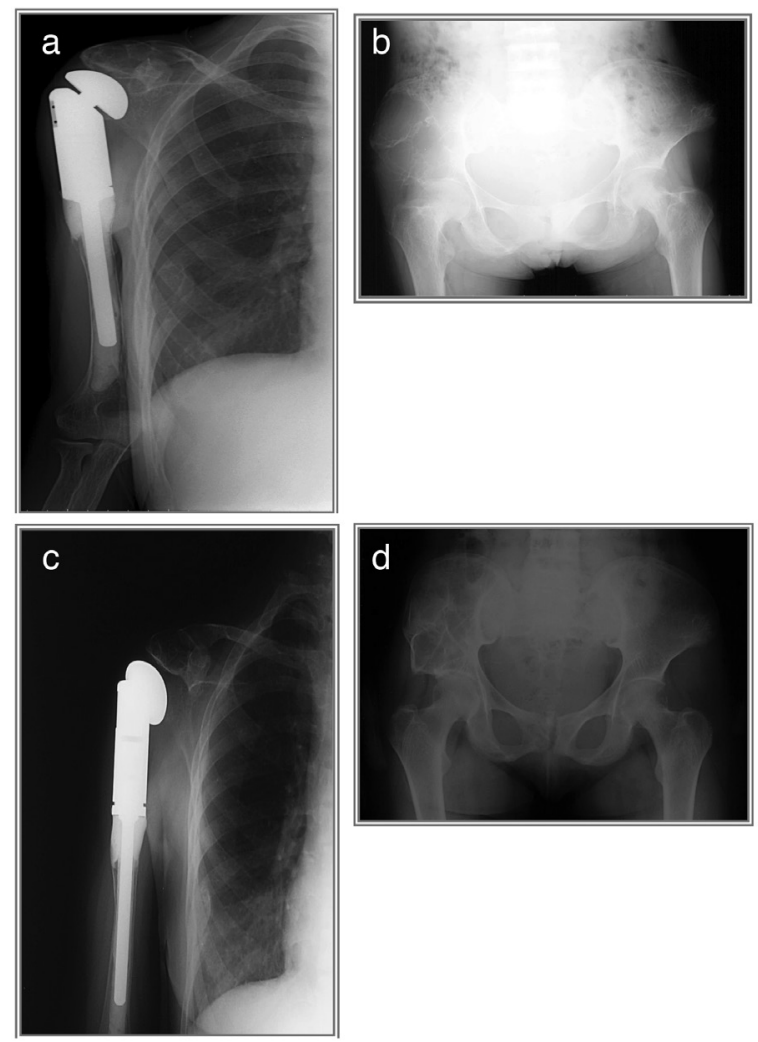

Figure 1. A 19-year-old female patient who underwent eccentric tumor resection due to right humeral lesion (patient numbered five) -; the significant change of the cyst in the iliac crest is particularly seen very well on the direct radiograph

a: Distal lesions of the acromion and clavicle of the patient, b: Large cystic lesion in the right half of the iliac crest, c and d: Control radiographs of the patient three years after the parathyroidectomy mimic all kinds of lesions and may be atypical. If the PTH effect is not eliminated, relapse will occur in the same or another site, regardless of how BTs are treated.
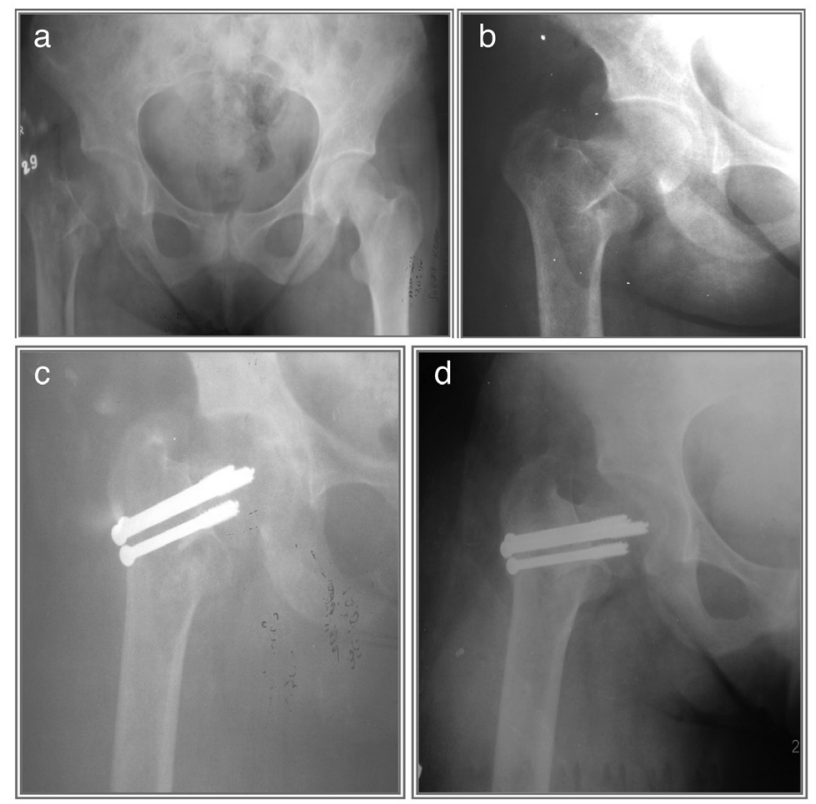

Figure 2. A 31-year-old female patient who underwent osteosynthesis due to a femoral neck fracture (patient numbered four) $\mathrm{a}$ and $\mathrm{b}$ : Proximal femur fracture radiographs, c: Post-operative radiograph first day, d: bone fusion six months after the surgery

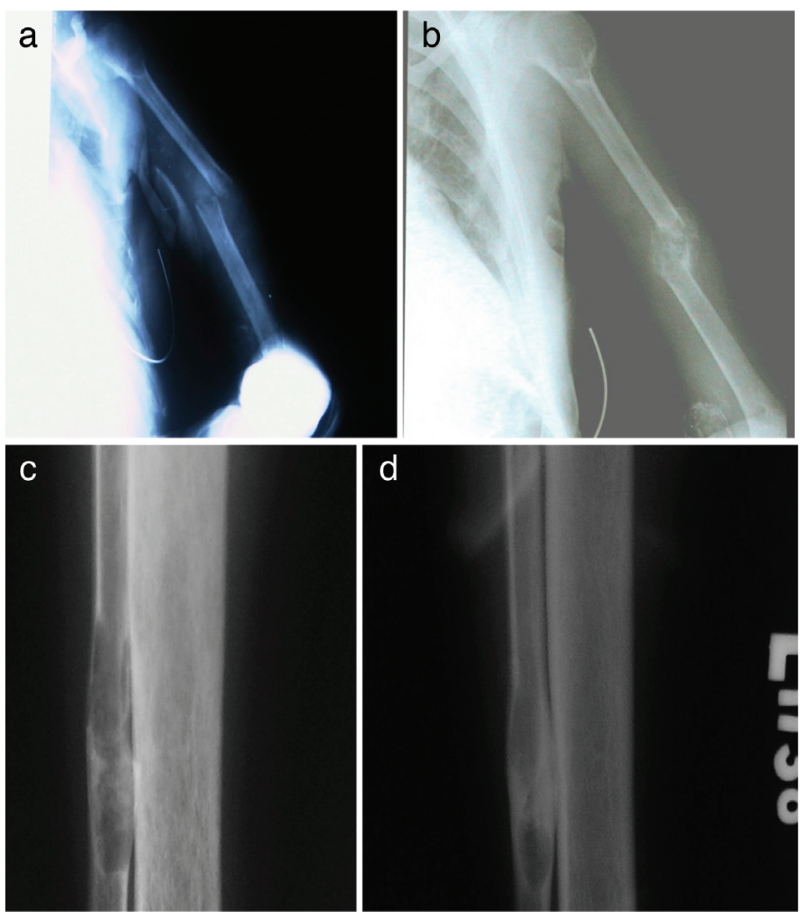

Figure 3. Patient numbered seven

$a$ and b: First fracture and four-month follow-up radiograph of the patient who admitted to our clinic because of the pathologic fracture of the left humerus, $c$ and $d$ : Anteroposterior radiography of the patient (patient numbered three) at the time of the first diagnosis of the cyst in the right fibula and one-year follow-up radiograph 
Pezzilo et al. (10) treated a femoral cyst case with the diagnosis of aneurysmal bone cyst and an isolated humerus cyst case with the diagnosis of GCT. Jouan et al. (11) applied a brutal operation for a BT case by performing fifth ray amputation. Some studies diagnosed osteolytic lesion of the distal ulna and radius as GCT and they performed resection to ulna and curettage and cement to the radius $(12,13)$. Rossi et al. (14) reported that asymptomatic PHPT should be followed after adenoma excision. After excision, the curettage and denosumab are good treatment since there was no regression in the cyst. Ouzaa et al. (15) reported that performig curettage, cementoplasty, and iliac bone graft for GCT was successful. Similarly, in a patient included in our study, curettage and cementoplasty were performed for the eccentric lytic lesion on the talus, which was diagnosed as GCT (patient numbered 10). Another patient in our series underwent tumor resection prosthesis with the diagnosis of primary bone malignancy, which was actually lytic lesion in the humerus, however, similar lesions were observed in other parts of the body in the post-operative follow-up and treatment. In the first examinations of the patient, the diagnosis of PHPT was made and the cysts were followed up (patient numbered 5, Figure 1).

BT is mostly seen in the craniofacial localization (15-19). Since we included patients who applied to the orthopedics outpatient clinic, the number of patients with lesions in the craniofacial region was two. The most involved area was the femur which was seen in 9 patients out of 12 .

Particularly in patients presenting with multiple bone involvement, BTs mimic bone metastases is the first diagnosis come to mind since it is common (19-22). Therefore, patients are diagnosed with PHPT during primary tumor investigation and continue their treatment as simpler and more satisfying. Since we analyzed the calcium, PTH and phosphorus values of the patients presenting with cystic bone lesions during the examination phase, we made very few mistakes in such a large number of complicated patients. De Crea et al. (23) reported that they performed right leg amputation in one patient and en bloc resection in one patient. Kirdak et al. (24), PHPT patients in two different countries were compared and it was reported that patients with PHPT in the developing country had higher serum PTH levels, more bone lesions, and larger adenomas. We believe that the wrong diagnosis and over-treatment are started to be more frequent in the differential diagnosis since PHPT-related BTs are seen less in developed countries.

Particular attention should be paid in differential diagnosis because GCT of bone, enchondroma, and aneurysmal bone tumor are very similar to BTs (6). It is important to note that histological examination alone is not sufficient to make a diagnosis. Therefore, it would be the most accurate and reliable approach to eliminate the diagnosis of PHPT by performing a simple blood test before performing the biopsy.

Once the adenoma is removed, the lesions are rapidly regressing and the bone is able to gain its former strength $(3,7,8,16-18)$. The results of the patients followed in our strongly support this treatment (Figure 3). Particularly BTs developed in the lower extremity load-bearing bones can cause pain and pathological fracture. Therefore, the lesion should be treated surgically. Simple methods should be preferred in surgery and existing bone stock of the patient should be preserved. In a study by Yang et al. (25), which is one of the largest BT series in the literature, three of eight patients had pathological fractures. All of the fractures were in the lower extremities that were treated surgically. Our approach was similar to the literature; we treated our patients as it was a tumor in the diagnosis, while as a fracture in the treatment. Therefore, no overtreatment was observed in our patients (Figure $2,3)$. It should be noted that lesions in other regions will disappear following removal of the adenoma. The most important matter is to keep these pathologies in mind during the diagnosis process and to suspect the diagnosis. The reason we report very few wrong procedures with the largest CT case in the literature may be the fact that the necessity of taking blood tests for PHPT in every patient with bone cyst or tumor before the biopsy stage is learned clearly during the education process.

\section{Study Limitations}

One of the limitations of our study was its retrospective pattern. The other limitation was the patient number. But we believe that our case number was good to report for a very rare disease. Another limitation was the absence of the control group to compare. But this is theoretically impossible to designate a control group for a comparison for this disease.

\section{Conclusion}

Evaluating the laboratory tests well during the treatment of the BTs in the orthopaedic discipline before proceeding to invasive procedures protect both the patient and physicians from over and wrong treatments.

\section{Ethics}

Ethics Committee Approval: This study was approved by the Fatih Sultan Mehmet Training and Research Hospital Institutional Review Board/Ethics Committee and conducted according to the ethical principles stated in the Declaration of Helsinki (decision no: 17073117-050.06, date: 03.02.2020).

Informed Consent: After approval of the institutional review board, informed consent was obtained from the all participants. Peer-review: Internally peer-reviewed.

\section{Authorship Contributions}

Surgical and Medical Practices: Y.Ö., H.M.Ö., Concept: Y.Ö., B.E.K., Design: B.E.K., Data Collection or Processing: A.V., E.A.Y., Analysis or Interpretation: B.E.K., Literature Search: O.G., Y.Ö., Writing: Y.Ö., B.E.K.

Conflict of Interest: No conflict of interest was declared by the authors.

Financial Disclosure: The authors declared that this study received no financial support. 


\section{References}

1. Bilezikian JP, Brandi ML, Rubin M, Silverberg SJ. Primary hyperparathyroidism: new concepts in clinical, densitometric and biochemical features. J Intern Med 2005;257:6-17.

2. Parisien M, Silverberg SJ, Shane E, Dempster DW, Bilezikian JP. Bone disease in primary hyperparathyroidism. Endocrinol Metab Clin North Am 1990;19:19-34.

3. Ishikawa S, Ozaki T, Kawai A, Inoue H, Doihara H. Hyperparathyroid crisis in a patient with a giant brown tumor of the iliac bone: a case report. Hiroshima J Med Sci 1998;47:27-30

4. Favus MJ. Primer on Metabolic Bone Diseases and Disorders of Mineral Metabolism. 2th ed. Lippincott - Raven; 1993.

5. Mirra JM, Campanacci M, Picci P. Brown tumor of hyperparathyroidism. In: Mirra JM, editor. Bone Tumors. Lea \& Febiger; 1989. p. 1785-801.

6. Peimer CA, Moy OJ, Dick HM. Tumors of bone and soft tissue. In: Green DP, editor. Operative hand surgery. New York: Churchill Livingstone; 1992. p. 2225-50.

7. Morano S, Cipriani R, Gabriele A, Medici F, Pantellini F Recurrent brown tumors as initial manifestation of primary hyperparathyroidism. An unusual presentation. Minerva Med 2000;91:117-22.

8. Aoune S, Khochtali H, Dahdouh C, Turki A, Mokni M, Bakir A. Giant cell lesions of the maxilla disclosing primary hyperparathyroidism. Rev Stomatol Chir Maxillofac 2000;101:86-9.

9. Cicconetti A, Matteini C, Piro FR. Differential diagnosis in a case of brown tumor caused by primary hyperparathyroidism. Minerva Stomatol 1999;48:553-8.

10. Pezzillo F, Di Matteo R, Liuzza F, Visci F, Callà C, Rosa MA, et al. Isolated bone lesion secondary to hyperparathyroidism: diagnostic considerations. Clin Ter 2008;159:265-8.

11. Jouan A, Zabraniecki L, Vincent V, Poix E, Fournié B. An unusual presentation of primary hyperparathyroidism: severe hypercalcemia and multiple brown tumors. Joint Bone Spine 2008;75:209-11.

12. Panagopoulos A, Tatani I, Kourea HP, Kokkalis ZT, Panagopoulos K, Megas P. Osteolytic lesions (brown tumors) of primary hyperparathyroidism misdiagnosed as multifocal giant cell tumor of the distal ulna and radius: a case report. J Med Case Rep 2018; $12: 176$.

13. Vera L, Dolcino M, Mora M, Oddo S, Gualco M, Minuto F, et al. Primary hyperparathyroidism diagnosed after surgical ablation of a costal mass mistaken for giant-cell bone tumor: a case report. J Med Case Rep 2011;5:596.
14. Rossi B, Ferraresi $V$, Appetecchia ML, Novello M, Zoccali C. Giant cell tumor of bone in a patient with diagnosis of primary hyperparathyroidism: a challenge in differential diagnosis with brown tumor. Skeletal Radiol 2014;43:693-7.

15. Ouzaa MR, Bennis A, Iken M, Abouzzahir A, Boussouga M, Jaafar A. Primary hyperparathyroidism associated with a giant cell tumor: One case in the distal radius. Chir Main 2015;34:260-3.

16. Kar DK, Gupta SK, Agarwal A, Mishra SK. Brown tumor of the palate and mandible in association with primary hyperparathyroidism. J Oral Maxillofac Surg 2001;59:1352-4.

17. Emin AH, Süoğlu $Y$, Demir D, Karatay MC. Normocalcemic hyperparathyroidism presented with mandibular brown tumor: report of a case. Auris Nasus Larynx 2004;31:299-304.

18. Tunali S, Celik HH, Uslu SS, Aldur MM. Scanning electron microscopic observation of the brown tumor of the head of mandible. Saudi Med J 2005;26:856-8.

19. Lessa MM, Sakae FA, Tsuji RK, Filho BC, Voegels RL, Butugan O. Brown tumor of the facial bones: case report and literature review. Ear Nose Throat J 2005;84:432-4.

20. Hsieh MC, Ko JY, Eng HL. Pathologic fracture of the distal femur in osteitis fibrosa cystica simulating metastatic disease. Arch Orthop Trauma Surg 2004;124:498-501.

21. Hoshi M, Takami M, Kajikawa M, Teramura K, Okamoto T, Yanagida I, et al. A case of multiple skeletal lesions of brown tumors, mimicking carcinoma metastases. Arch Orthop Trauma Surg 2008;128:149-54.

22. Joyce JM, Idea RJ, Grossman SJ, Liss RG, Lyons JB. Multiple brown tumors in unsuspected primary hyperparathyroidism mimicking metastatic disease on radiograph and bone scan. Clin Nucl Med 1994; 19:630-5.

23. De Crea C, Traini E, Oragano L, Bellantone C, Raffaelli M, Lombardi CP. Are brown tumours a forgotten disease in developed countries? Acta Otorhinolaryngol Ital 2012:32:410-5.

24. Kirdak T, Duh QY, Kebebew E, Clark OH. Do patients undergoing parathyroidectomy for primary hyperparathyroidism in San Francisco, CA, and Bursa, Turkey, differ? Am J Surg 2009;198:18892.

25. Yang Q, Sun P, Li J, Yang Z, Li X, Li Z, et al. Skeletal lesions in primary hyperparathyroidism. Am J Med Sci 2015;349:321-7. 